Article

\title{
Inhibition of TGF- $\beta$ Signaling in Gliomas by the Flavonoid Diosmetin Isolated from Dracocephalum peregrinum $\mathrm{L}$.
}

\author{
Yuli Yan ${ }^{1,2}{ }^{\infty}$, Xingyu Liu ${ }^{1}$, Jie Gao ${ }^{3}$, Yin $\mathrm{Wu}^{1, *}$ and Yuxin $\mathrm{Li}^{3, *}$ \\ 1 National Engineering Laboratory for Druggable Gene and Protein Screening, Northeast Normal University, \\ Jilin 130107, China; yanyl721@nenu.edu.cn (Y.Y.); liuxy013@nenu.edu.cn (X.L.) \\ 2 School of pharmacy, Changchun University of Chinese Medicine, Jilin 130107, China \\ 3 Research Center of Agriculture and Medicine gene Engineering of Ministry of Education, \\ Northeast Normal University, Jilin 130107, China; gaoj813@nenu.edu.cn \\ * Correspondence: wuy705@nenu.edu.cn (Y.W.); liyx486@nenu.edu.cn (Y.L.); Tel.: +86-138-4485-6743 (Y.W.)
}

Received: 26 November 2019; Accepted: 1 January 2020; Published: 2 January 2020

check for updates

\begin{abstract}
Background: Dracocephalum peregrinum L., a traditional Kazakh medicine, has good expectorant, anti-cough, and to some degree, anti-asthmatic effects. Diosmetin ( $3^{\prime}, 5,7$-trihydroxy-4' methoxyflavone), a natural flavonoid found in traditional Chinese herbs, is the main flavonoid in $D$. peregrinum $\mathrm{L}$. and has been used in various medicinal products because of its anticancer, antimicrobial, antioxidant, estrogenic, and anti-inflammatory effects. The present study aimed to investigate the effects of diosmetin on the proliferation, invasion, and migration of glioma cells, as well as the possible underlying mechanisms. Methods: 3-(4,5-dimethylthiazol-2-yl)-2,5-diphenyltetrazolium bromide (MTT), scratch wound, and Transwell assays were used to demonstrate the effects of diosmetin in glioma. Protein levels of Bcl-2, Bax, cleaved caspase-3, transforming growth factor- $\beta$ (TGF- $\beta$ ), E-cadherin, and phosphorylated and unphosphorylated smad 2 and $\operatorname{smad} 3$ were determined by Western blots. U251 glioma cell development and progression were measured in vivo in a mouse model. Results: Diosmetin inhibited U251 cell proliferation, migration, and invasion in vitro, the TGF- $\beta$ signaling pathway, and Bcl-2 expression. In contrast, there was a significant increase in E-cadherin, Bax, and cleaved caspase-3 expression. Furthermore, it effectively reduced the tumorigenicity of glioma cells and promoted apoptosis in vivo. Conclusion: The results of this study suggest that diosmetin suppresses the growth of glioma cells in vitro and in vivo, possibly by activating E-cadherin expression and inhibiting the TGF- $\beta$ signaling pathway.
\end{abstract}

Keywords: Dracocephalum peregrinum; diosmetin; glioma cells; TGF- $\beta$; E-cadherin

\section{Introduction}

Gliomas, the most common primary and lethal type of tumor in the central nervous system (WHO grade IV), are an aggressive form of brain cancer with a 5-year median survival rate of less than $5 \%[1,2]$. They are characterized by their rapid infiltrating growth, migration ability, and invasive tumor growth [3,4]. Moreover, glioma cells show proliferation, diffuse infiltration, high resistance to apoptosis, degradation of the extracellular matrix, and stimulation of cell migratory signaling pathways, thereby facilitating the invasion of healthy brain tissue $[5,6]$. The treatment for gliomas typically involves surgical resection and a combination of chemotherapy and radiotherapy. Despite such treatments, the effect on overall survival is minimal $[7,8]$. Therefore, there is clearly a pressing clinical need to develop novel therapeutic strategies to improve the outcomes for gliomas, identify critical carcinogenic pathways, and discover new therapeutic targets for gliomas. In this regard, the flavonoid diosmetin, isolated from Dracocephalum peregrinum, is currently under investigation. 
Furthermore, on the basis of recent technological advances, numerous Chinese medicines that affect the development of gliomas in vivo and in vitro have been identified [9-12], providing new research clues for the diagnosis and treatment of this type of cancer.

D. peregrinum is a herb belonging to the Labiatae family. It is widely distributed in the northern territory of China and is a medicinal herb that has been used in traditional Kazakh medicine to treat cold and liver diseases. D. peregrinum is known as "Tekanbasjelanbas" and "tikanbasgarambas" in the Kazakh language and has been documented as Kazakhstani medicine in records such as the Kazak Journal of Medicine, Flora of Chinese, and Flora of Xinjiang.

Diosmetin is an O-methylated flavone (3',5,7-trihydroxy-4'-methoxyflavone) (Figure 1A) that is abundant in olive leaves (Olea europaea L.), citrus fruits (and in related products, e.g., lemon or bergamot juice), and extracts of some medicinal herbs [13,14]. Furthermore, the main flavonoid of $D$. peregrinum, diosmetin, exhibits a large variety of pharmacological activities, such as anti-inflammatory, antioxidative, anticancer, and antiremodeling effects in various disorders [15-17]. Furthermore, it can selectively induce apoptosis and inhibit the growth of cancer cells without affecting the growth of normal cells [18]. Previous studies have shown that diosmetin can ameliorate pancreatitis by inhibiting the generation of proinflammatory mediators such as interleukin (IL)- $1 \beta$, IL-6, and tumor necrosis factor- $\alpha$ (TNF- $\alpha)$ [19]. Moreover, diosmetin has been shown to suppress the proliferation of various tumor cells, such as hepatic carcinoma, breast cancer, leucocythemia, and prostate cancer cells [13,20-22]. However, to the best of our knowledge, there has been no definitive report on the effect of diosmetin on glioma cells. Thus, in this study, we aimed to investigate the effects of diosmetin on glioma cells in vitro and in vivo and its ability to induce their apoptosis.
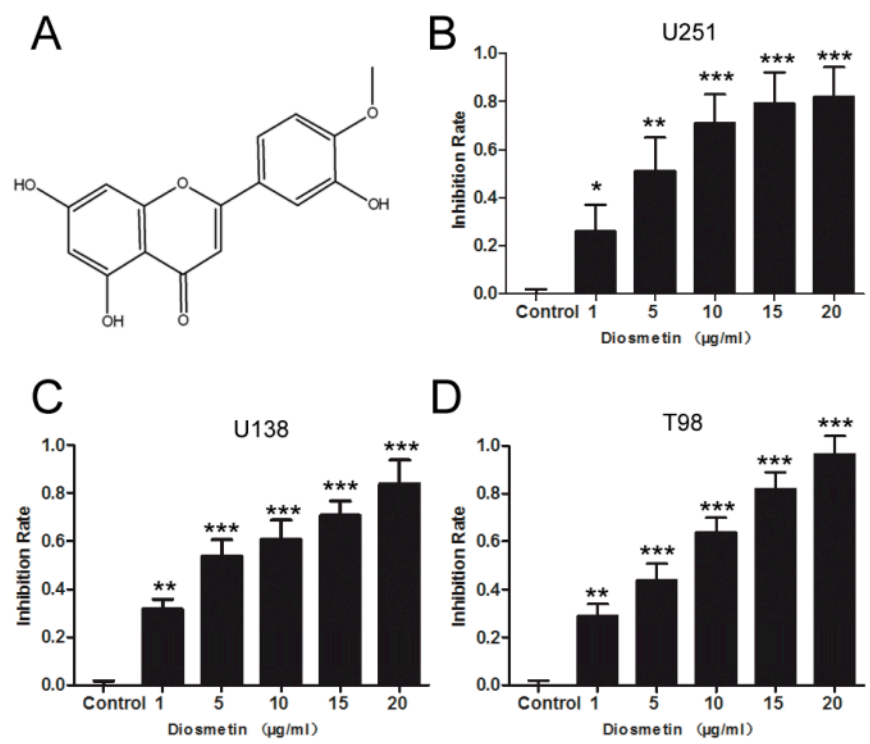

Figure 1. Diosmetin inhibited the proliferation of glioma cells. (A) The structure of diosmetin. MTT assay for the case of cell proliferation of (B) U251, (C) U183, and (D) T98; $n=6$, and the data are presented as the mean \pm standard deviation. Compared with the control group, ${ }^{*} p<0.05,{ }^{* *} p<0.01$, *** $p<0.001$.

\section{Results}

\subsection{Diosmetin Inhibits the Proliferation, Invasion, and Migration of Glioma Cells}

MTT, cell scratch, and Transwell assays were carried out to investigate the effects of diosmetin on the proliferation, migration, and invasiveness of glioma cells. Cell proliferation was significantly reduced in cultures exposed to diosmetin (Figure 1B-D). More importantly, the viability of cells treated with $5,10,15$, and $20 \mu \mathrm{g} / \mathrm{mL}$ diosmetin for $72 \mathrm{~h}$ was effectively reduced to $49.2 \%, 29.8 \%, 21.5 \%$, and $18.3 \%$ that of untreated cells, respectively (inhibition of $50.8 \%, 70.2 \%, 76.5 \%$, and $80.3 \%$, respectively), 
in U251 cells; the inhibition was 56.3\%, 62.5\%, 73.6\%, and 82.7\%, respectively, in U138 cells, and $45.8 \%, 64.8 \%, 80.7 \%$, and $93.1 \%$, respectively, in T98 cells. The U251 cell line was selected for further experiments. The scratch-healing rate, an indicator of cell migration, of the diosmetin-treated cell group was significantly lower than that of the control group at both 12 and $24 \mathrm{~h}$ (Figure $2 \mathrm{~A}-\mathrm{C} ; p<0.01$, $p<0.01)$. Furthermore, the invasiveness of the cells was reduced significantly after treatment with $10 \mu \mathrm{g} / \mathrm{mL}(42.1 \pm 6.74)$ and $20 \mu \mathrm{g} / \mathrm{mL}(38.5 \pm 4.74)$ diosmetin compared with that of the control group $(84.4 \pm 8.62)$ (Figure 2D,E; $p<0.01, p<0.001)$. In summary, diosmetin inhibited the proliferation, invasion, and migration of glioma cells.

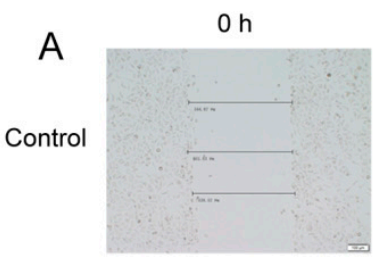

5

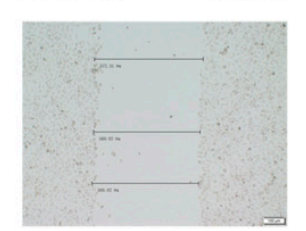

10

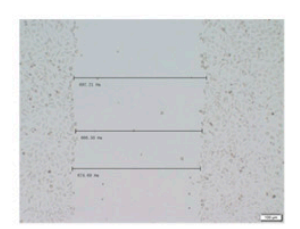

20

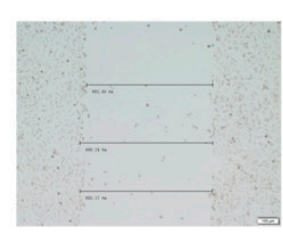

D
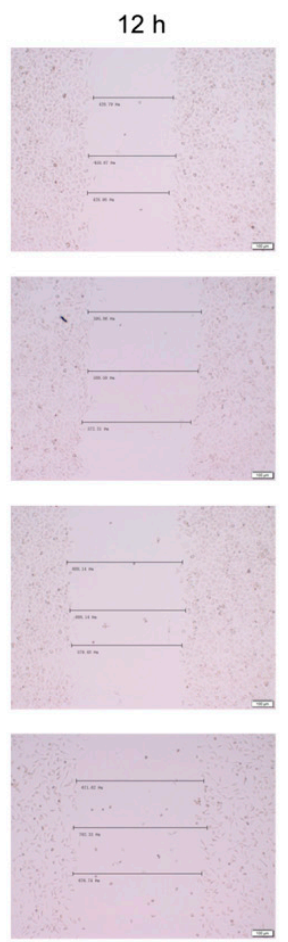

Control

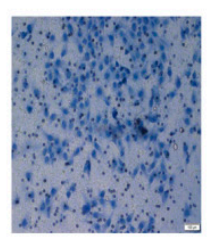

5

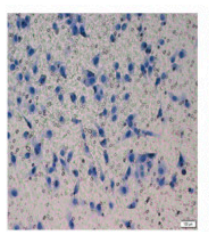

10

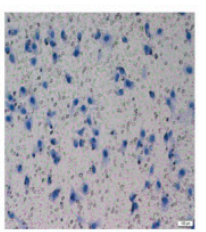

$24 \mathrm{~h}$

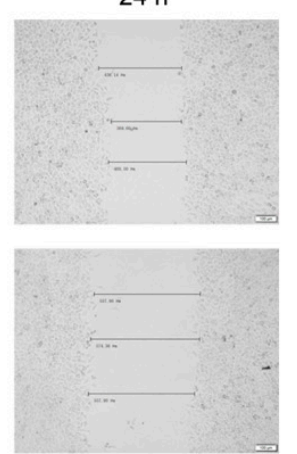

B

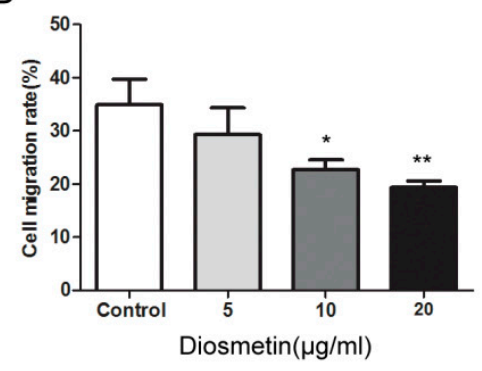

C

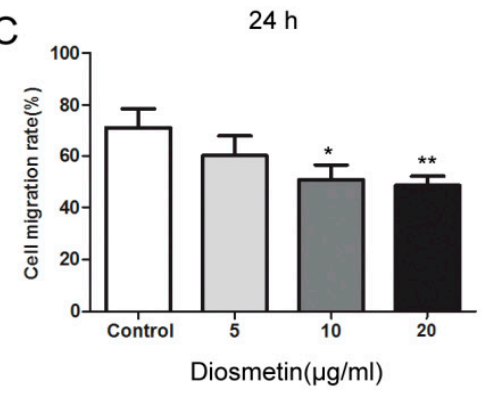

E

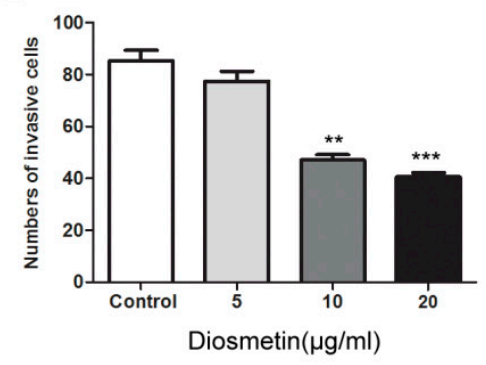

Figure 2. Diosmetin inhibited the invasion and migration of glioma cells. (A-C) Cell-scratching assays.

(D,E) Transwell assays. Compared with group, ${ }^{*} p<0.05,{ }^{* *} p<0.01,{ }^{* * *} p<0.001$.

\subsection{Diosmetin Induces the Apoptosis of Glioma Cells}

The results of flow cytometry showed that diosmetin significantly induced the apoptosis of U251 cells. The apoptosis ratio in the diosmetin 10 and $20 \mu \mathrm{g} / \mathrm{mL}$ groups was 0.98 and 2.54 times that in the control group, respectively (Figure $3 \mathrm{~A}, \mathrm{~B} ; p<0.01, p<0.001$ ); thus, apoptosis in the diosmetin group was increased compared with that in the control group. To elucidate the effect of diosmetin on the U251 cells, the levels of Bcl-2, Bax, and cleaved caspase- 3 in different treatment groups were determined. The result indicated that the expression of Bcl-2 in the diosmetin $20 \mu \mathrm{g} / \mathrm{mL}$ group was only $71 \%$ of that in the control group (Figure 3C,D; $p<0.001$ ), while that of cleaved caspase-3 and Bax was 1.58 
(Figure 3C,E; $p<0.01$ ) and 1.63 (Figure 3C,F; $p<0.01$ ) times that of the control group, which indicates that diosmetin can induce the apoptosis of U251 cells.
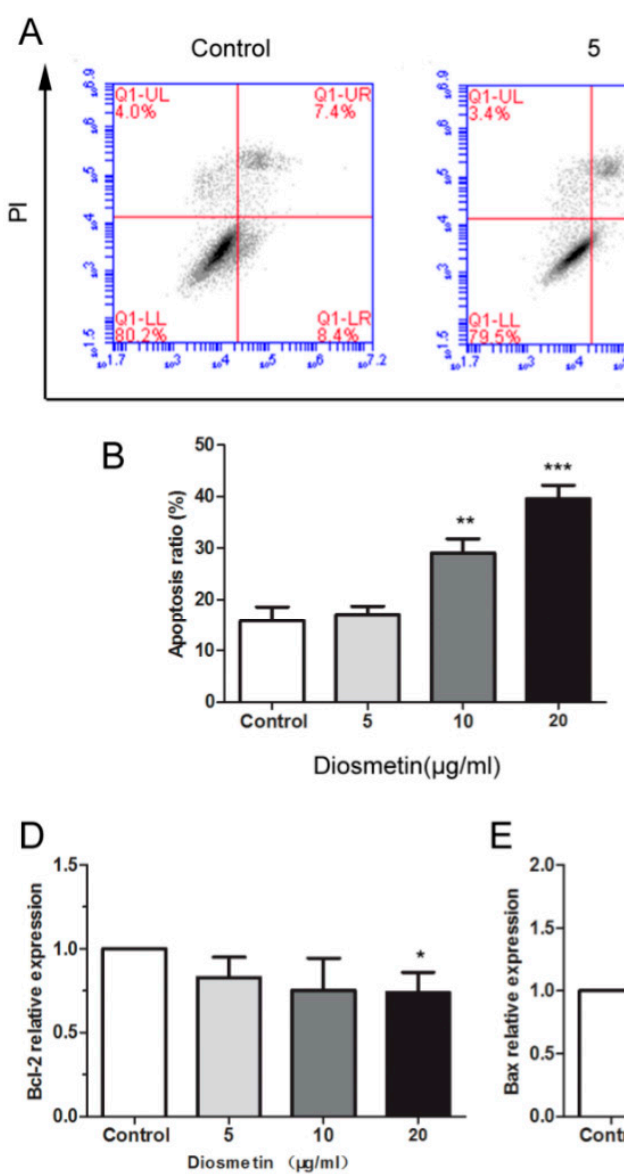

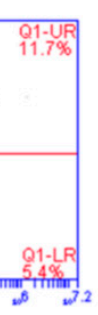

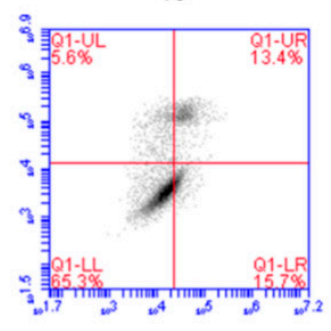

20

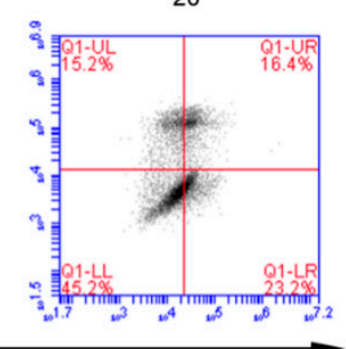

Annexin V-FITC

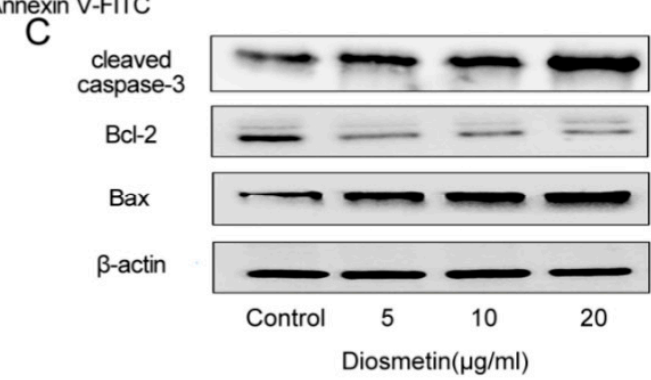

F
E

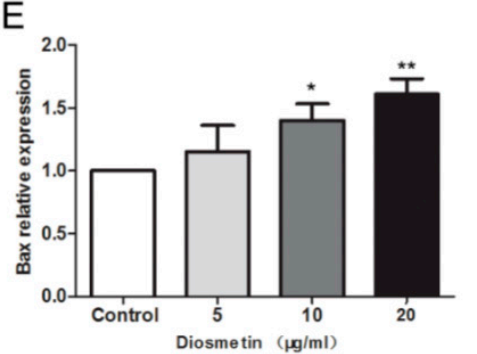

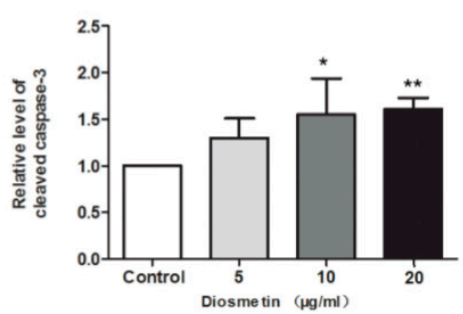

Figure 3. Diosmetin induced the apoptosis of glioma cells. (A,B) Flow cytometry analysis to examine cell apoptosis; (C-F) Western blot analysis was used to determine the expression of Bcl-2, Bax, cleaved caspase- 3 in different groups. $\beta$-actin was used as an internal control for grayscale analysis. Compared with the control group, ${ }^{*} p<0.05,{ }^{* *} p<0.01$.

2.3. Diosmetin Leads to Inhibition of the TGF- $\beta$ Signaling Pathway and Activation of E-Cadherin Expression in Glioma Cells

TGF- $\beta$ signaling and E-cadherin play key roles in tumor cell progression. To assess the activation of E-cadherin, we investigated the molecular mechanism of diosmetin-regulated cell migration and invasiveness. Compared with the corresponding control group levels, the protein levels of TGF- $\beta 1$, p-Smad2, and p-Smad3 decreased by $46.3 \%, 23.5 \%$, and $28.6 \%$ in the diosmetin $10 \mu \mathrm{g} / \mathrm{mL}$ group, respectively (Figure $4 \mathrm{~A}-\mathrm{C}, p<0.001, p<0.05, p<0.01$ ), and $51.2 \%, 28.5 \%$, and $41.3 \%$ in the diosmetin $20 \mu \mathrm{g} / \mathrm{mL}$ group, respectively (Figure $4 \mathrm{~A}-\mathrm{C} ; p<0.001, p<0.01, p<0.001$ ). In contrast, E-cadherin expression increased by almost $50 \%$ in U251 cells due to 10 and $20 \mu \mathrm{g} / \mathrm{mL}$ of diosmetin treatment (Figure 4A,E-G, $p<0.01, p<0.001$ ). The results of these assays demonstrate that diosmetin increases the expression of E-cadherin and inhibits the TGF- $\beta$ signaling pathway. 

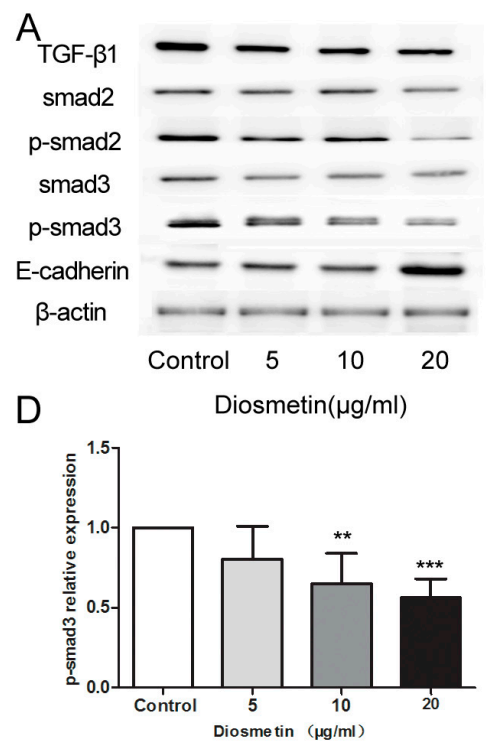

G

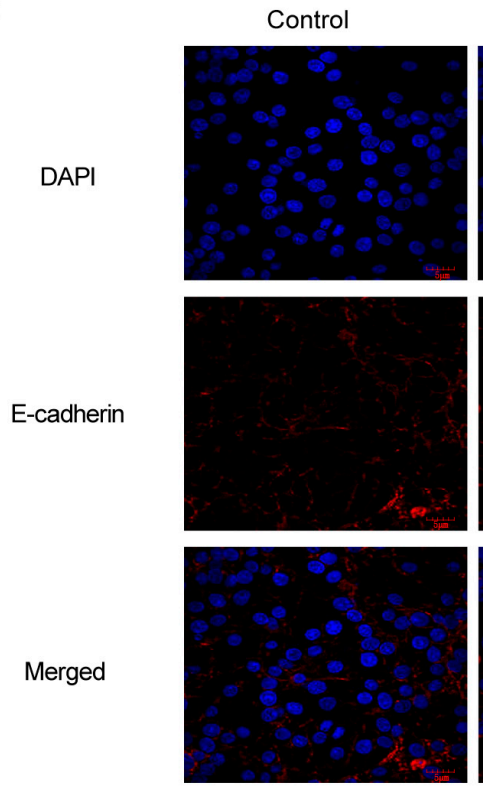

B

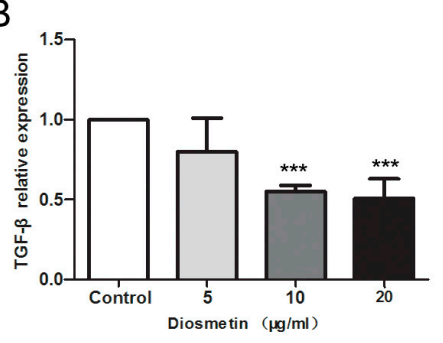

E

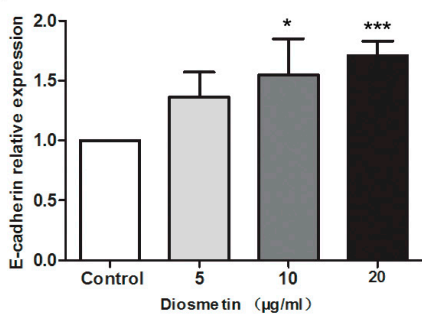

C

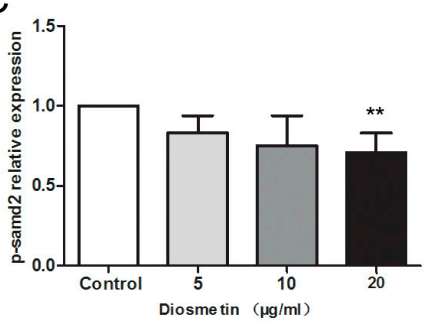

F

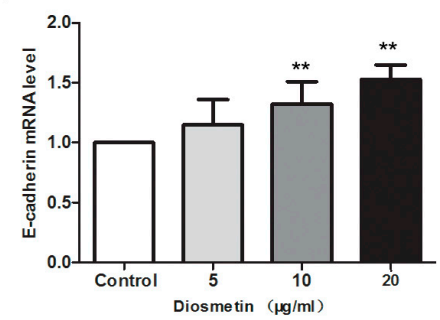

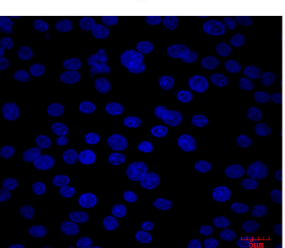

10
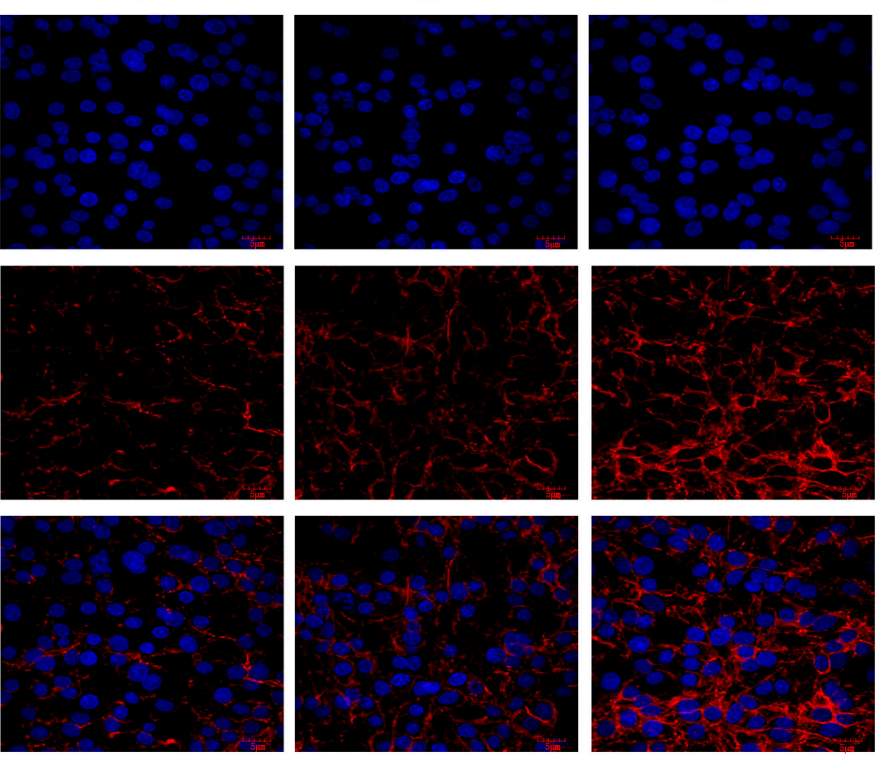

Figure 4. Diosmetin led to inhibition of the TGF- $\beta$ signaling pathway and activation of E-cadherin expression in glioma cells. Western blot assay was performed to detect the protein levels of $(\mathbf{A}, \mathbf{B})$ TGF- $\beta 1$, $(\mathbf{A}, \mathbf{C})$ p-smad2, (A,D) p-smad3 and (A,E) E-cadherin, with the grayscale analysis using $\beta$-actin as the internal control. (F) Real-time PCR was used to detect the expression level of E-cadherin mRNA. (G) Immunofluorescence staining was performed to observe the distribution of E-cadherin protein in glioma cells. Compared with control group, ${ }^{*} p<0.05,{ }^{* *} p<0.01,{ }^{* * *} p<0.001$.

\subsection{Diosmetin Inhibits Glioma Tumor Growth In Vivo}

Using a mouse model of glioma, we investigated the effects of diosmetin on U251 glioma cells. In the control group, the mean tumor weight of $2.43 \mathrm{~g}$ and volume of $1.89 \mathrm{~mm}^{3}$ were significantly higher than those in the other groups, with the values in the diosmetin $20 \mu \mathrm{g} / \mathrm{mL}$ group being the lowest (mean weight of $1.39 \mathrm{~g}$ and volume of $1.08 \mathrm{~mm}^{3}$; Figure $5 \mathrm{~A}-\mathrm{C}$ ). These results indicate that diosmetin can slow tumor growth, and this effect is dose-dependent. 


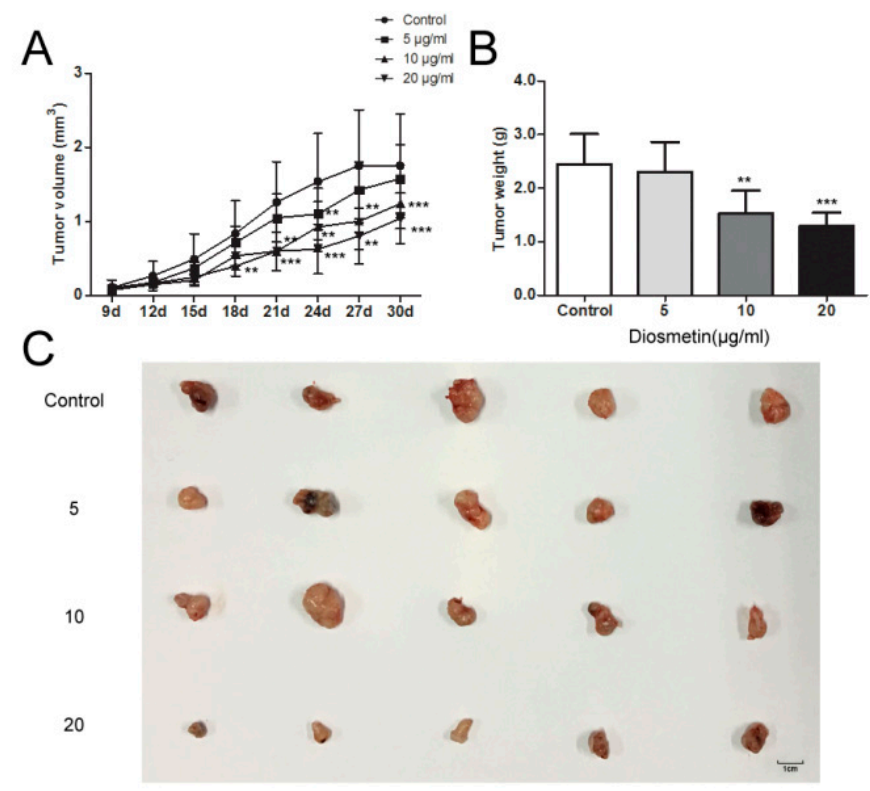

Figure 5. Diosmetin inhibited glioma tumor growth in vivo. (A) Tumor volume assay, (B) tumor weight assay, and $(\mathbf{C})$ the photo of the tumor tissue. This figure shows the typical result of repeated experiments, and the data are presented as the mean \pm standard deviation. Compared with the control group, ${ }^{* *} p<0.01,{ }^{* * *} p<0.001$.

\section{Discussion}

Glioma remains one of the most common malignancies worldwide, and the associated morbidity and mortality continue to increase yearly [1]. The median survival is generally less than 1 year from the time of diagnosis, and even under the most favorable situations, most patients die within 2 years [7]. Diosmetin has been previously demonstrated to induce cell apoptosis and act as an anticancer compound in several cancers [23-26]. However, the effects of diosmetin on glioma have not been elucidated, and whether diosmetin can affect glioma development and the underlying mechanisms remains unknown. In the present study, we researched the effects of diosmetin on U251 glioma cancer cells. We found that it inhibited the proliferation, migration, invasion, and cell apoptosis of U251 glioma cancer cells by regulating the TGF- $\beta$ signaling pathway, and that it promoted apoptosis in glioma xenograft tumors in nude mice. These findings demonstrate that diosmetin inhibits the proliferation and promotes the apoptosis of U251 glioma cancer in vitro and in vivo, indicating that diosmetin may be a promising novel drug for glioma.

Cell proliferation, migration, invasion, and apoptosis play important roles in cell growth $[27,28]$. The levels of cleaved caspase-3, Bcl-2, and Bax in cells can directly regulate apoptosis [29]. Caspase-3, one of the most important proteins in the caspase family, plays a major role in the final phase of apoptosis. The ratio of Bax and Bcl-2, a pair of proteins that complement each other in the Bcl-2 family, plays an important role in the regulation of intrinsic apoptotic signaling [30,31]. The results of the present study show that diosmetin effectively promotes apoptosis, downregulates the levels of Bcl-2, and elevates the levels of Bax and cleaved caspase-3 in glioma cells.

The TGF- $\beta$ superfamily of proteins, ubiquitous in cells, are widely involved in cell development and progression, and their excessive expression is found in a variety of tumors including lung, liver, breast, and ovarian cancers [32-35]. The Smad cytoplasmic proteins, a series of key proteins in the TGF- $\beta$ signaling pathway, are present in both normal and transformed cells [36]. TGF- $\beta$ signaling plays its role in regulating cell growth by binding its type I and type II receptors and inducing the phosphorylation of Smad2 and Smad3 [37]. It has been reported that the levels of TGF- $\beta 1$ and phosphorylated Smads are upregulated in some malignant tumors $[38,39]$. In the present study, we showed that diosmetin inhibits TGF- $\beta$ signaling in glioma cells by suppressing the expression of TGF- $\beta$ 
and elevating the levels of the active forms of Smad proteins (i.e., p-Smad2 and p-Smad3). These findings are consistent with those of previous reports on other tumor types.

E-cadherin, a single-chain transmembrane glycoprotein, maintains the morphology and structural integrity of epithelial cells and plays an important regulatory role in the epithelial-mesenchymal transition (EMT) [40]. Reducing or eliminating the expression of E-cadherin can induce EMT, which affords tumor cells strong metastatic and invasive capabilities [41]. The expression level of E-cadherin in various tumors has been shown to be reduced [42], while the low expression level in the brain of patients with glioma is associated with an increased risk of EMT, which can lead to deterioration of the glioma [43]. Our experiments show that the expression of E-cadherin was increased in the diosmetin groups, suggesting that diosmetin increases the expression of E-cadherin through the TGF- $\beta$ signaling pathway, thus inhibiting malignant metastasis and invasion of glioma cells.

\section{Materials and Methods}

\subsection{Plant Material}

In this study, the medicinal material used was the whole plant of $D$. peregrinum obtained from the Tori Region in northwestern Xinjiang in the autumn of 2014. The herb was stored at room temperature and identified by the Xinjiang Food and Drug Administration as belonging to the Labiatae family. Plant specimens were preserved in the National Engineering Laboratory for Drug Gene and Protein Screening in Northeast Normal University.

\subsection{Isolation of Diosmetin from D. peregrinum}

Air-dried D. peregrinum was cut into 3-cm-long pieces, and then refluxed three times with $70 \%$ ethyl alcohol. The resulting ethyl alcohol extract was successively fractionated with petroleum ether, chloroform, ethyl acetate, and n-butanol. The chloroform fraction was then separated by silica gel column chromatography with chloroform-methanol (100:0, 70:1, 50:1, 20:1, 5:1, 2:1, 0:100) to yield seven fractions. The yield was about $0.028 \%$ (chloroform fraction $80.0 \mathrm{~g}$, diosmetin $25.0 \mathrm{mg}$ ). The effective fractions were purified using Sephadex-LH20 and analyzed by ${ }^{1} \mathrm{H}$ NMR and ${ }^{13} \mathrm{C}$ NMR (Table 1).

Table 1. ${ }^{1} \mathrm{H}$ and ${ }^{13} \mathrm{C}$ NMR spectral data of diosmetin observed at $400 / 100 \mathrm{MHz}$ in DMSO- $d_{6}$.

\begin{tabular}{ccc}
\hline Pos. & ${ }^{\delta} \mathbf{H}$ (mult., $\boldsymbol{J}$ in Hz) & ${ }^{\delta} \mathbf{C}$ \\
\hline 2 & - & 163.50 \\
3 & $6.73(\mathrm{~s})$ & 103.72 \\
4 & - & 181.66 \\
5 & 12.91 & 157.29 \\
6 & $6.18(\mathrm{~d}, 2.0 \mathrm{~Hz})$ & 98.84 \\
7 & 10.80 & 164.17 \\
8 & $6.45(\mathrm{~d}, 1.6 \mathrm{~Hz})$ & 93.87 \\
9 & - & 161.43 \\
10 & - & 103.50 \\
$1^{\prime}$ & - & 118.68 \\
$2^{\prime}$ & $7.41(\mathrm{~d}, 2.4 \mathrm{~Hz})$ & 112.93 \\
$3^{\prime}$ & 9.41 & 146.76 \\
$4^{\prime}$ & - & 151.11 \\
$5^{\prime}$ & $7.07(1 \mathrm{H}, \mathrm{d}, 8.4 \mathrm{~Hz})$ & 112.14 \\
$6^{\prime}$ & $7.53(1 \mathrm{H}, \mathrm{dd}, 2.0,8.4 \mathrm{~Hz})$ & 122.98 \\
$-\mathrm{OCH}_{3}$ & $3.85(3 \mathrm{H}, \mathrm{s})$ & 55.74 \\
\hline
\end{tabular}

\subsection{Cell Culture}

The human glioma cell lines U251, U138, and T98 were obtained from the Shanghai Cell Bank, Type Culture Collection Committee, Chinese Academy of Sciences (Shanghai, China). The cells were cultured in Dulbecco's modified Eagle's medium (DMEM, Gibco, Invitrogen, Grand Island, NE, USA) 
containing 10\% fetal bovine serum (FBS, HyClone, Logan, UT, USA), penicillin (100 U/mL), and streptomycin $(100 \mu \mathrm{g} / \mathrm{mL})$ in a humidified atmosphere containing $5 \% \mathrm{CO}_{2}$ at $37^{\circ} \mathrm{C}$. Exponential phase cells were used in subsequent experiments.

\subsection{MTT Assay}

For the MTT assay, the cell suspension was diluted to a density of $2 \times 10^{3}$ cells/well. Then, $200 \mu \mathrm{L}$ of cell suspension was added to each well of 96-well plates and cultured for $24 \mathrm{~h}$, before discarding the supernatant. Subsequently, MTT (Sigma-Aldrich, St. Louis, MO, USA) was added at a final concentration of $0.2 \mathrm{mg} / \mathrm{mL}$, and the plates were incubated for $72 \mathrm{~h}$. The medium was then replaced, and the cells were further cultured for $4 \mathrm{~h}$ at $37^{\circ} \mathrm{C}$ in a humidified atmosphere with $5 \% \mathrm{CO}_{2}$. The medium was removed, and then $200 \mu \mathrm{L}$ of dimethyl sulfoxide (DMSO, Sigma-Aldrich, St. Louis, MO, USA) was added. The plates were gently mixed for $15 \mathrm{~min}$ to dissolve the formazan crystals completely. The optical density was measured at $490 \mathrm{~nm}$ using an ELX-800 (BioTek, Winooski, VT, USA).

\subsection{Cell Scratch Assay}

U251 cells in the exponential growth phase were mixed with serum-free medium. The cell suspension was diluted to a density of $1 \times 10^{5}$ cells/well and inoculated in a six-well culture plate, with $200 \mu \mathrm{L}$ of suspension per well. A marker pen was used to draw two parallel, equidistant lines along the bottom of the wells; the plate was placed in a $5 \% \mathrm{CO}_{2}$ environment at $37^{\circ} \mathrm{C}$ for $24 \mathrm{~h}$ to aid cell confluency. Then, a 200- $\mu \mathrm{L}$ micropipette was used to scratch a line evenly in the cell monolayer between the two marker lines. After the scratch, the medium was slowly aspirated using a pipette, and the cells were washed twice with serum-free medium to remove cell debris. The six-well plate was placed under an inverted microscope to observe and acquire images; the migration distance of the cells before and after incubation was measured, and the migration rate was calculated.

\subsection{Transwell Assay}

Cells in the exponential growth phase were digested with $0.25 \%$ trypsin without EDTA, and the diluted cell density was $2 \times 10^{4}$ cells/well. The cells were resuspended with serum-free cell culture medium, and then seeded in the upper chamber of a Transwell apparatus precoated with Matrigel (Corning Incorporated Life Sciences, Tewksbury, MA, USA). The lower chamber was supplemented with $5 \%$ FBS. The cells were then cultured for $24 \mathrm{~h}$ in an incubator. The Transwell semipermeable membrane was removed, washed with PBS, fixed with paraformaldehyde for $20 \mathrm{~min}$, and stained with $0.1 \%$ crystal violet for $30 \mathrm{~min}$. To remove cells that did not migrate through the semipermeable membrane, the upper surface was wiped gently with cotton three times using PBS. Migratory cells on the bottom of the membrane were observed and counted (five random fields) under a $400 \times$ microscope, and the invasive ability of the cells was calculated as the number of cells penetrating the membrane.

\subsection{Flow Cytometric Analysis of Apoptosis}

Apoptotic cells were detected using the Annexin V-PI Apoptosis Detection Kit (KeyGEN BioTECH, Nanjing, China) and flow cytometry (FACSCalibur, BD, Franklin Lakes, NJ, USA) according to the manufacturer's instructions. Cells were added to a six-well cell culture plate and incubated for $24 \mathrm{~h}$. The medium was discarded, and the cell pellet was collected, washed twice with cold PBS, stained with $400 \mu \mathrm{L}$ of $1 \times$ Annexin $\mathrm{V}$ and $5 \mu \mathrm{L}$ of Annexin V-FITC, and incubated at $2-8^{\circ} \mathrm{C}$ for $15 \mathrm{~min}$ in the dark. Subsequently, $10 \mu \mathrm{L}$ of PI was added after staining by liquid blending and incubated at $2-8{ }^{\circ} \mathrm{C}$ in the dark for $15 \mathrm{~min}$. Cell apoptosis was then analyzed by flow cytometry.

\subsection{Western Blotting}

The cells were lysed, collected, and cleared using the total protein extraction kit (Beyotime Institute of Biotechnology, Haimen, China). The extracts were then subjected to sodium dodecyl 
sulfate-polyacrylamide gel electrophoresis (SDS-PAGE) (10\% separating gel, $4 \%$ stacking gel). The proteins were electro-transferred onto a polyvinylidene fluoride membrane and blocked with $5 \%$ non-fat milk at room temperature. The membrane was incubated with specific rabbit monoclonal primary antibodies (cleaved caspase-3, Bax, Bcl-2, TGF- $\beta$, Smad2, p-Smad2, Smad3, p-Smad3, E-cadherin, or $\beta$-actin, 1:1000; Bioss, Beijing, China) at $4{ }^{\circ} \mathrm{C}$ overnight and then incubated with horseradish peroxidase (HRP)-labeled goat anti-rabbit secondary antibody. The proteins were visualized using enhanced chemiluminescence (ECL) reagents (Qihai Biotec, Shanghai, China). Gel-Pro Analyzer software was used for imaging, and the signals were normalized using $\beta$-actin as the internal control.

\subsection{Immunofluorescence Staining}

The cultured cells were digested with $0.25 \%$ trypsin, fully dispersed into a single cell suspension, and grown on a glass slide. When the cells were close to confluence, the culture medium was discarded, and the cells were washed three times with PBS and fixed with $4 \%$ paraformaldehyde for $20 \mathrm{~min}$. The glass slide was removed and washed twice with PBS, and then $0.1 \%$ Triton X-100 was added and incubated for $20 \mathrm{~min}$. Thereafter, the cells were incubated with E-cadherin antibody (1:50; Beyotime) at $4{ }^{\circ} \mathrm{C}$ overnight. The washed cells were then incubated with Cy3-labeled goat anti-rabbit secondary antibody (Beyotime) for $1 \mathrm{~h}$ at room temperature and washed three times with PBS. After counter-staining the nuclei with DAPI, a laser confocal microscope (Olympus, Tokyo, Japan) was used to observe the images at $600 \times$ magnification.

\subsection{Real-Time Polymerase Chain Reaction}

Total RNA was prepared from cells using an RNA extraction kit (TIANGEN Biotech, Beijing, China). cDNA was then synthesized by reverse transcription. SYBR GREEN master mix (TIANGEN) was used for real-time PCR in an Exicycler ${ }^{\mathrm{TM}} 96$ Real-Time Quantitative Thermal block (Bioneer, Daejeon, Korea), with $\beta$-actin as the internal control. The primers are listed in Table 2. The total qPCR reaction volume was $20 \mu \mathrm{L}$ and consisted of $1 \mu \mathrm{L}$ of cDNA, $0.5 \mu \mathrm{L}$ of each primer, $10 \mu \mathrm{L}$ of SYBR GREEN master mix, and $8 \mu \mathrm{L}$ of $\mathrm{ddH}_{2} \mathrm{O}$. The PCR reaction program was as follows: $95^{\circ} \mathrm{C}$ for $10 \mathrm{~min} ; 40$ cycles of $95^{\circ} \mathrm{C}$ for $10 \mathrm{~s}, 58^{\circ} \mathrm{C}$ for $20 \mathrm{~s}$, and $72{ }^{\circ} \mathrm{C}$ for $30 \mathrm{~s}$; and $4{ }^{\circ} \mathrm{C}$ for $5 \mathrm{~min}$.

Table 2. Sequences of the primers for real-time PCR.

\begin{tabular}{cc}
\hline Primer Name & Sequence $\left(\mathbf{5}^{\prime} \mathbf{-} \mathbf{3}^{\prime} \mathbf{)}\right.$ \\
\hline E-cadherin F & ATGCCGCCATCGCTTACAC \\
E-cadherin R & CGACGTTAGCCTCGTTCTCA \\
$\beta$-actin F & CTTAGTTGCGTTACACCCTTTCTTG \\
$\beta$-actin R & CTGTCACCTTCACCGTTCCAGTTT \\
\hline
\end{tabular}

\subsection{In Vivo Experiments}

In vivo experiments were conducted using pathogen-free BALB/c nude mice at 4-6 weeks of age, provided by the Beijing Vital River Laboratory Animal Technology Co. Ltd. (Beijing, China). The mice were housed in laboratory facilities at a temperature range of $21.0-25.0^{\circ} \mathrm{C}$, relative humidity of $40.0 \%-70.0 \%$, and $12 \mathrm{~h} \mathrm{light/dark} \mathrm{cycle;} \mathrm{the} \mathrm{air} \mathrm{was} \mathrm{exchanged} \mathrm{at} \mathrm{least} 15$ times per hour. The mice had free access to food and water. The care and treatment of the mice were approved by the Experimental Animal Ethics Committee of China Medical University. After one week of acclimatization, the mice were randomly assigned to the following four groups ( $\mathrm{n}=5$ per group): $\mathrm{U} 251,5 \mu \mathrm{g} / \mathrm{mL}$ diosmetin (i.v.), $10 \mu \mathrm{g} / \mathrm{mL}$ diosmetin (i.v.), and $20 \mu \mathrm{g} / \mathrm{mL}$ diosmetin (i.v.). The cells $\left(1 \times 10^{6}\right)$ were suspended in $0.2 \mathrm{~mL}$ of normal saline and then injected subcutaneously into the right side of the breast pad of the nude mice. Tumor volumes were calculated as follows: volumes $=a \times b^{2} / 2$, where $a$ is the larger of the two dimensions and $b$ is the smaller. The mice were euthanized after 30 days and their tumors were weighed and photographed. 


\subsection{Data Analysis}

Data are presented as means \pm standard deviations. Comparisons between groups were performed using one-way analysis of variance, and multiple comparisons were performed using Bonferroni post-hoc tests. Data and figures were processed using GraphPad Prism 5.0 software. $p<0.05$ was considered statistically significant.

\section{Conclusions}

Taken together, the results of the present study demonstrate that diosmetin inhibits the proliferation, invasion, and migration of glioma cells and increases the expression of the metastasis-related factor E-cadherin via the TGF- $\beta$ signaling pathway. Our preliminary data suggest that diosmetin plays a key role in the malignant progression of gliomas and suggests that diosmetin can be further explored as a therapy drug for gliomas.

Author Contributions: Conceptualization, Y.L.; Methodology, Y.Y. and X.L.; Software, J.G.; Validation, Y.W.; Formal Analysis, J.G.; Investigation, Y.Y.; Resources, Y.L.; Data Curation, Y.W.; Writing-Original Draft Preparation, Y.Y.; Writing-Review \& Editing, Y.L.; Visualization, X.L.; Supervision, Y.W.; Project Administration, Y.L.; Funding Acquisition, Y.L. All authors have read and agreed to the published version of the manuscript.

Funding: This study was supported by grants from the following foundations: the National Natural Science Foundation of China (NSFC) (No. 81502284, 817007096), the Fundamental Research Funds for the Central Universities (No. 130028701-5, 2412018QD011), the Research Foundation of Jilin Provincial Science \& Technology Development (No. 20150101188JC, 20150204038YY, 20150309003YY, 20170623051TC, 20170414028GH, 20170520031JH, 20180520105JH, 20180101242JC), and the Changchun Science and Technology Committee (No. 17YJ003).

Conflicts of Interest: We wish to draw the attention of the Editor to the following facts that may be considered as potential conflicts of interest and to significant financial contributions to this work.

Availability of Data and Materials: The [DATA TYPE] data used to support the findings of this study are included within the article. Including: Graphpad Prism 5.0 software.

Patient Consent for Publication: Not applicable.

\section{Abbreviations}

FBS

MTT

TGF- $\beta$

TNF- $\alpha$ fetal bovine serum

3-(4,5-dimethylthiazol-2-yl)-2,5-diphenyltetrazolium bromide

transforming growth factor- $\beta$

tumor necrosis factor- $\alpha$

\section{References}

1. Gladson, C.L.; Prayson, R.A.; Liu, W.M. The pathobiology of glioma tumors. Annu. Rev. Pathol. 2010, 5, 33-50. [CrossRef]

2. Rutter, E.M.; Stepien, T.L.; Anderies, B.J.; Plasencia, J.D.; Woolf, E.C.; Scheck, A.C.; Turner, G.H.; Liu, Q.; Frakes, D.; Kodibagkar, V.; et al. Mathematical Analysis of Glioma Growth in a Murine Model. Sci. Rep. 2017, 7, 2508. [CrossRef]

3. Cloughesy, T.F.; Cavenee, W.K.; Mischel, P.S. Glioblastoma: From molecular pathology to targeted treatment. Annu. Rev. Pathol. 2014, 9,1-25. [CrossRef]

4. Lu, J.; Zhang, M.; Yang, X.; Cui, T.; Dai, J. MicroRNA-548c-3p inhibits T98G glioma cell proliferation and migration by downregulating c-Myb. Oncol. Lett. 2017, 13, 3866-3872. [CrossRef]

5. Cuddapah, V.A.; Robel, S.; Watkins, S.; Sontheimer, H. A neurocentric perspective on glioma invasion. Nat. Rev. Neurosci. 2014, 15, 455-465. [CrossRef]

6. Kutwin, M.; Sawosz, E.; Jaworski, S.; Wierzbicki, M.; Strojny, B.; Grodzik, M.; Chwalibog, A. Assessment of the proliferation status of glioblastoma cell and tumour tissue after nanoplatinum treatment. PLoS ONE 2017, 12, e0178277. [CrossRef] 
7. Stupp, R.; Mason, W.P.; van den Bent, M.J.; Weller, M.; Fisher, B.; Taphoorn, M.J.; Belanger, K.; Brandes, A.A.; Marosi, C.; Bogdahn, U.; et al. Radiotherapy plus concomitant and adjuvant temozolomide for glioblastoma. N. Engl. J. Med. 2005, 352, 987-996. [CrossRef] [PubMed]

8. Cockle, J.V.; Bruning-Richardson, A.; Scott, K.J.; Thompson, J.; Kottke, T.; Morrison, E.; Ismail, A.; Carcaboso, A.M.; Rose, A.; Selby, P.; et al. Oncolytic Herpes Simplex Virus Inhibits Pediatric Brain Tumor Migration and Invasion. Mol. Ther. Oncol. 2017, 5, 75-86. [CrossRef] [PubMed]

9. Tsai, Y.J.; Chen, I.L.; Horng, L.Y.; Wu, R.T. Induction of differentiation in rat C6 glioma cells with Saikosaponins. Phytother. Res. 2002, 16, 117-121. [CrossRef] [PubMed]

10. Jeong, J.C.; Kim, S.J.; Kim, Y.K.; Kwon, C.H.; Kim, K.H. Lycii cortex radicis extract inhibits glioma tumor growth in vitro and in vivo through downregulation of the Akt/ERK pathway. Oncol. Rep. 2012, 27, 1467-1474.

11. Evirgen, O.; Gokce, A.; Ozturk, O.H.; Nacar, E.; Onlen, Y.; Ozer, B.; Motor, V.K. Effect of Thymoquinone on Oxidative Stress in Escherichia coli-Induced Pyelonephritis in Rats. Curr. Ther. Res. Clin. Exp. 2011, 72, 204-215. [CrossRef] [PubMed]

12. Huang, C.; Luo, Y.; Zhao, J.; Yang, F.; Zhao, H.; Fan, W.; Ge, P. Shikonin kills glioma cells through necroptosis mediated by RIP-1. PLoS ONE 2013, 8, e66326. [CrossRef] [PubMed]

13. Ge, A.; Liu, Y.; Zeng, X.; Kong, H.; Ma, Y.; Zhang, J.; Bai, F.; Huang, M. Effect of diosmetin on airway remodeling in a murine model of chronic asthma. Acta Biochim. Biophys. Sin. Shanghai 2015, 47, 604-611. [CrossRef] [PubMed]

14. Chen, J.J.; Zhang, J.X.; Zhang, X.Q.; Qi, M.J.; Shi, M.Z.; Yang, J.; Zhang, K.Z.; Guo, C.; Han, Y.L. Effects of diosmetin on nine cytochrome P450 isoforms, UGTs and three drug transporters in vitro. Toxicol. Appl. Pharmacol. 2017, 334, 1-7. [CrossRef] [PubMed]

15. Lee, S.J.; Jung, T.H.; Kim, H.; Jeong, D.; Choi, G.; Park, W.K.; Kong, J.Y.; Jin, M.H.; Cho, H. Inhibition of c-Kit signaling by diosmetin isolated from Chrysanthemum morifolium. Arch. Pharm. Res. 2014, 37, 175-185. [CrossRef] [PubMed]

16. Patel, K.; Gadewar, M.; Tahilyani, V.; Patel, D.K. A review on pharmacological and analytical aspects of diosmetin: A concise report. Chin. J. Integr. Med. 2013, 19, 792-800. [CrossRef]

17. Poor, M.; Veres, B.; Jakus, P.B.; Antus, C.; Montsko, G.; Zrinyi, Z.; Vladimir-Knezevic, S.; Petrik, J.; Koszegi, T. Flavonoid diosmetin increases ATP levels in kidney cells and relieves ATP depleting effect of ochratoxin A. J. Photochem. Photobiol. B 2014, 132, 1-9. [CrossRef]

18. Roma, A.; Rota, S.G.; Spagnuolo, P.A. Diosmetin Induces Apoptosis of Acute Myeloid Leukemia Cells. Mol. Pharm. 2018, 15, 1353-1360. [CrossRef]

19. Yu, G.; Wan, R.; Yin, G.; Xiong, J.; Hu, Y.; Xing, M.; Cang, X.; Fan, Y.; Xiao, W.; Qiu, L.; et al. Diosmetin ameliorates the severity of cerulein-induced acute pancreatitis in mice by inhibiting the activation of the nuclear factor-kappaB. Int. J. Clin. Exp. Pathol. 2014, 7, 2133-2142.

20. Androutsopoulos, V.P.; Mahale, S.; Arroo, R.R.; Potter, G. Anticancer effects of the flavonoid diosmetin on cell cycle progression and proliferation of MDA-MB 468 breast cancer cells due to CYP1 activation. Oncol. Rep. 2009, 21, 1525-1528.

21. Yang, K.; Li, W.F.; Yu, J.F.; Yi, C.; Huang, W.F. Diosmetin protects against ischemia/reperfusion-induced acute kidney injury in mice. J. Surg. Res. 2017, 214, 69-78. [CrossRef] [PubMed]

22. Liu, B.; Jia, K.; Yang, Y.; Hao, S.; Lu, C.; Xu, F.; Feng, D.; Zhu, R. Diosmetin Induces Cell Apoptosis by Regulating CYP1A1/CYP1A2 Due to p53 Activation in HepG2 Cells. Protein. Pept. Lett. 2017, 24, 406-412. [CrossRef] [PubMed]

23. Yang, Y.; Gong, X.B.; Huang, L.G.; Wang, Z.X.; Wan, R.Z.; Zhang, P.; Zhang, Q.Y.; Chen, Z.; Zhang, B.S. Diosmetin exerts anti-oxidative, anti-inflammatory and anti-apoptotic effects to protect against endotoxin-induced acute hepatic failure in mice. Oncotarget 2017, 8, 30723-30733. [CrossRef] [PubMed]

24. Liu, J.; Ren, H.; Liu, B.; Zhang, Q.; Li, M.; Zhu, R. Diosmetin inhibits cell proliferation and induces apoptosis by regulating autophagy via the mammalian target of rapamycin pathway in hepatocellular carcinoma HepG2 cells. Oncol. Lett. 2016, 12, 4385-4392. [CrossRef] [PubMed]

25. Ge, A.; Liu, Y.; Zeng, X.; Kong, H.; Ma, Y.; Zhang, J.; Bai, F.; Huang, M. Diosmetin prevents TGF-beta1-induced epithelial-mesenchymal transition via ROS/MAPK signaling pathways. Life Sci. 2016, 153, 1-8. [CrossRef] 
26. Oak, C.; Khalifa, A.O.; Isali, I.; Bhaskaran, N.; Walker, E.; Shukla, S. Diosmetin suppresses human prostate cancer cell proliferation through the induction of apoptosis and cell cycle arrest. Int. J. Oncol. 2018, 53, 835-843. [CrossRef]

27. Schonberg, D.L.; Lubelski, D.; Miller, T.E.; Rich, J.N. Brain tumor stem cells: Molecular characteristics and their impact on therapy. Mol. Asp. Med. 2014, 39, 82-101. [CrossRef]

28. Qiao, J.; Liu, J.; Jia, K.; Li, N.; Liu, B.; Zhang, Q.; Zhu, R. Diosmetin triggers cell apoptosis by activation of the p53/Bcl-2 pathway and inactivation of the Notch3/NF-kappaB pathway in HepG2 cells. Oncol. Lett. 2016, 12, 5122-5128. [CrossRef]

29. Raschella, G.; Melino, G.; Gambacurta, A. Cell death in cancer in the era of precision medicine. Genes Immun. 2018, 20, 529-538. [CrossRef]

30. Zarnescu, O.; Brehar, F.M.; Chivu, M.; Ciurea, A.V. Immunohistochemical localization of caspase-3, caspase-9 and Bax in U87 glioblastoma xenografts. J. Mol. Histol. 2008, 39, 561-569. [CrossRef]

31. Bhattacharjee, M.; Acharya, S.; Ghosh, A.; Sarkar, P.; Chatterjee, S.; Kumar, P.; Chaudhuri, S. Bax and Bid act in synergy to bring about T11TS-mediated glioma apoptosis via the release of mitochondrial cytochrome $\mathrm{C}$ and subsequent caspase activation. Int. Immunol. 2008, 20, 1489-1505. [CrossRef] [PubMed]

32. Raja-Khan, N. The role of TGF-beta in polycystic ovary syndrome. Reprod. Sci. 2014, 21, 20-31. [CrossRef] [PubMed]

33. Zhang, G.; Zhao, Q.; Yu, S.; Lin, R.; Yi, X. Pttg1 inhibits TGFbeta signaling in breast cancer cells to promote their growth. Tumour. Biol. 2015, 36, 199-203. [CrossRef] [PubMed]

34. Araz, O.; Demirci, E.; Ucar, E.Y.; Calik, M.; Karaman, A.; Durur-Subasi, I.; Orsal, E.; Subasi, M.; Daloglu, F.; Akgun, M. Roles of Ki-67, p53, transforming growth factor-beta and lysyl oxidase in the metastasis of lung cancer. Respirology 2014, 19, 1034-1039. [CrossRef] [PubMed]

35. Drabsch, Y.; Ten Dijke, P. TGF-beta signalling and its role in cancer progression and metastasis. Cancer Metastasis Rev. 2012, 31, 553-568. [CrossRef] [PubMed]

36. Liu, L.; Dai, Q.; Min, Z.; Zhang, M. [Transforming growth factor beta1 enhances the invasiveness of human glioma cell line via ERK/MAPK pathway]. Nan Fang Yi Ke Da Xue Xue Bao 2013, 33, 1744-1747.

37. Kamato, D.; Burch, M.L.; Piva, T.J.; Rezaei, H.B.; Rostam, M.A.; Xu, S.; Zheng, W.; Little, P.J.; Osman, N. Transforming growth factor-beta signalling: Role and consequences of Smad linker region phosphorylation. Cell Signal. 2013, 25, 2017-2024. [CrossRef]

38. Kang, H.; Lee, M.; Jang, S.W. Celastrol inhibits TGF-beta1-induced epithelial-mesenchymal transition by inhibiting Snail and regulating E-cadherin expression. Biochem. Biophys. Res. Commun. 2013, 437, 550-556. [CrossRef]

39. Li, X.; Miyajima, M.; Jiang, C.; Arai, H. Expression of TGF-betas and TGF-beta type II receptor in cerebrospinal fluid of patients with idiopathic normal pressure hydrocephalus. Neurosci. Lett. 2007, 413, 141-144. [CrossRef]

40. Katayama, M.; Hirai, S.; Yasumoto, M.; Nishikawa, K.; Nagata, S.; Otsuka, M.; Kamihagi, K.; Kato, I. Soluble fragments of e-cadherin cell-adhesion molecule increase in urinary-excretion of cancer-patients, potentially indicating its shedding from epithelial tumor-cells. Int. J. Oncol. 1994, 5, 1049-1057. [CrossRef]

41. Thiery, J.P.; Acloque, H.; Huang, R.Y.; Nieto, M.A. Epithelial-mesenchymal transitions in development and disease. Cell 2009, 139, 871-890. [CrossRef] [PubMed]

42. Tanaka, M.; Kitajima, Y.; Edakuni, G.; Sato, S.; Miyazaki, K. Abnormal expression of E-cadherin and beta-catenin may be a molecular marker of submucosal invasion and lymph node metastasis in early gastric cancer. Br. J. Surg. 2002, 89, 236-244. [PubMed]

43. Min, S.; Xiaoyan, X.; Fanghui, P.; Yamei, W.; Xiaoli, Y.; Feng, W. The glioma-associated oncogene homolog 1 promotes epithelial-mesenchymal transition in human esophageal squamous cell cancer by inhibiting E-cadherin via Snail. Cancer Gene. Ther. 2013, 20, 379-385. [CrossRef] [PubMed]

Sample Availability: Not available.

(C) 2020 by the authors. Licensee MDPI, Basel, Switzerland. This article is an open access article distributed under the terms and conditions of the Creative Commons Attribution (CC BY) license (http://creativecommons.org/licenses/by/4.0/). 